\title{
Lesions in the musculature of captive American plaice Hippoglossoides platessoides caused by the fungus Hormoconis resinae (Deuteromycetes)
}

\author{
D. B. Strongman ${ }^{1, *}$, C. M. Morrison ${ }^{2}$, G. McClelland ${ }^{2}$ \\ 'Biology Department, Saint Mary's University, Halifax, Nova Scotia, Canada B3H 3C3 \\ ${ }^{2}$ Department of Fisheries and Oceans, Science Branch, PO Box 550, Halifax, Nova Scotia, Canada B3J 2S7
}

\begin{abstract}
A.BSTRACT: Round black lesions were found on the ventral side of 8 juvenile American plaice Hippoglossoides platessoides housed in the aquarium at the Department of Fisheries and Oceans Research Laboratory, Halifax, Nova Scotia, Canada. The wild plaice caught on Sable Island Bank, Nova Scotia, were held in 800 and $3200 \mathrm{l}$ tanks supplied with a continuous flow of fresh prefiltered seawater at ambient temperature. The lesions numbered 1 or 2 per fish, varied from 5 to $20 \mathrm{~mm}$ in diameter and usually had a large central crater. Light microscopy and SEM revealed that the ulcers were surrounded by a rim of hyperplastic epidermis and contained numerous branched, septate fungal hyphae and Gram-negative bacteria, host erythrocytes, macrophages, and cellular debris. Fungal hyphae and necrosis extended through the dermis and musculature to the vertebral column. While the epidermis was intact over smaller lesions, hyphae could be seen on the surface of the skin, and extending along the scales through the epidermis and into the dermis. The fungus was identified as Hormoconis (Cladosporium) resinae (Deuteromycetes), a species that is not only ubiquitous in terrestrial, freshwater and marine environments, but often occurs in petroleum products. This is the first record of the fungus as a pathogen in a marine organism.
\end{abstract}

KEY WORDS: Atlantic Disease Flat fish - Tank-reared

\section{INTRODUCTION}

Fungi cause serious diseases in economically important species of freshwater fish and crustaceans (Alderman 1982, Chacko 1992). Marine animals are also susceptible to fungal pathogens but, with a few exceptions, the impact of fungal disease in marine fishes is poorly understood (Alderman \& Polglase 1986, Sindermann 1990). Diseases caused by oomycete genera, e.g Lagenidium and Haliphthoros, are well documented from marine animals (Noga 1990), and Ascomycetes are known to infect commercially important crustaceans such as lobster and crab (Hibbets et al. 1981 Noga 1990). The role and impact of deuteromycete pathogens in the marine habitat are not well established, with reports of single-case infections constituting much of the available information. Ochroconis

\footnotetext{
•E-mail: doug.strongman@stmarys.ca
}

humicola was originally described from the kidney of freshwater salmon, but has more recently been reported from cultured marine devil stingers Inimicus japonicus, where it caused open ulcers (Wada et al. 1995). Exophiala piscifila is a virulent pathogen of several fish species (Noga 1990). Fusarium solani is a well-known plant pathogen in terrestrial habitats, but also is a serious opportunistic pathogen of crustaceans (Noga 1990, Sindermann 1990). This fungus is prevalent in intensive marine aquaculture operations where the frequency of wounding is high (Alderman \& Polglase 1986).

Fungi belonging to the deuteromycete genera Cladosporium or Hormoconis are seldom reported from marine fauna. C. sphaerospermum has been identified from an octopus (Polglase et al. 1984), and C. cladosporioides from lobster (Miller \& Flemming 1983). Cladosporium sp. was implicated in hyperplasia of gill epithelia in a North Sea cod Gadus morhua (Reichen- 
bach-Klinke 1956), but supporting evidence that the fungus was a primary infection was lacking (see Kinne 1984, p 109).

Histopathological studies of fungal pathogenesis in fish have shown that fungi can occur systemically or can be localized in surface lesions on the skin, gills or eyes (Roberts 1989. Noga 1993). Systemic infections are usually manifested as lesions or tumours on organs such as the liver, heart or kidney (Noga 1993). Wounds on fish are often colonized by a variety of microorganisms, including fungi, which can severely damage skin and muscle tissue.

In the following account we describe Hormoconis (=Cladosporium) resinae cultured from lesions in the skin and underlying tissues of American plaice held in seawater tanks, and show evidence that it can actively invade through the host integument.

\section{METHODS}

Capture and maintenance of plaice. Live juvenile American plaice Hippoglossoides platessoides were collected in the shoals and slope waters of northern and northwestern Sable Island Bank, Nova Scotia, Canada, from the 'Alfred E. Needler', 7-8 June 1992. The fish were caught at depths of 30 to $110 \mathrm{~m}$ with a modified Western IIA otter trawl. Tows were of 10 to 20 min duration at a speed of 2.8 knots. Plaice were held in $1.22 \times 0.91 \times 0.76 \mathrm{~m}, 850 \mathrm{l}$ capacity, insulated fish boxes supplied with aeration and a continuous flow of fresh 6 to $8^{\circ} \mathrm{C}$ seawater at 5 to $101 \mathrm{~min}^{-1}$

On return to the Department of Fisheries and Oceans Halifax Fisheries Research Laboratory, Nova Scotia, Canada, plaice were transferred to two $3.61 \times 0.75 \times$ $0.44 \mathrm{~m}, 800 \mathrm{I}$ capacity, fibreglass tanks provided with aeration, and a continuous flow of fresh seawater. The water was prefiltered through sand and gravel and drained via overflow standpipes. Seawater was at ambient temperature, with monthly means from -0.8 (range $=-1.2$ to -0.3$)^{\circ} \mathrm{C}$ in March to $11.0(6.8 \text { to } 15.2)^{\circ} \mathrm{C}$ in August and remaining above $9.0^{\circ} \mathrm{C}$ from September to November. The fish were not fed during their first $2 \mathrm{wk}$ in captivity, but were subsequently maintained on a diet of finely sliced herring Clupea harengus, squid Illex illecebrosus and shrimp Pandulus borealis. Fish were fed twice weekly during spring, summer and fall, and once weekly in winter.

After 10 wk in captivity (August 1992), lengths and weights of the 74 surviving plaice were recorded and a numbered spaghetti tag was affixed at the base of the fin rays of each fish. Larger specimens, mean $=27.3$ (22.2 to 31.2 ) $\mathrm{cm}$ in length and weighing an average of 157.8 (92.0 to 262.7) $\mathrm{g}(\mathrm{n}=52)$, were placed in a cylindrical tank, $1.83 \mathrm{~m}$ in diameter and $1.22 \mathrm{~m}$ deep, with a
3200 l capacity. This tank was supplied with aeration and a continuous flow of fresh, prefiltered seawater at $-61 \mathrm{~min}^{-1}$, and drained, initially, through an overflow valve on the side, and subsequently (May 1994), via an external standpipe drawing from the bottom. While temperatures of the seawater supply to the $3200 \mathrm{l}$ tank were similar to those in the $800 \mathrm{l}$ tanks in winter and spring, the former was equipped with a chiller and water temperature never exceeded $9.0^{\circ} \mathrm{C}$ during summer and fall.

Smaller fish, mean $=19.0(\mathrm{range}=10.2$ to 24.2$) \mathrm{cm}$ in length and mean weight $46.9(5.6$ to 93.8$) \mathrm{g}(\mathrm{n}=22)$, were returned to one of the $800 \mathrm{l}$ tanks, and used in a study of the migration of larval nematodes Pseudoterranova decipiens in host tissues. Movements of nematodes in the musculature of small plaice were monitored at monthly intervals between September 1992 and March 1993. Individual fish were confined in a shallow plexiglass box of seawater, and photographed using a light table system employing crosspolarizing filters. In April 1993, the 14 surviving plaice from the larva migrans study were transferred to the $3200 \mathrm{l}$ tank.

Fish with lesions were necropsied between January 1993 and Febuary 1994. Tissue samples of lesions on the head, body and fins, as well as samples of liver, kidney and gonad of necropsied plaice, were cultured for bacteria and fungi at 10 and $22^{\circ} \mathrm{C}$ on tryptic soy agar (TSA), TSA supplemented with $2 \%$ salt, thiosulphate citrate bile salts sucrose agar (TCBSA) supplemented with $2 \%$ salt, cytophaga agar. (CA), CA supplemented with $3 \%$ salt and CA in seawater (Austin \& Austin 1987). Tissue samples were also cultured on blood agar (BA), BA with $2 \%$ salt added, Shieh's medium (Shieh 1980) and Sabouraud dextrose agar (SDA) made with $50 \%$ seawater. Fungal isolates from SDA were subcultured at $25^{\circ} \mathrm{C}$ on $2 \%$ malt extract agar $(2 \% \mathrm{MEA})$ in $80 \%$ seawater and on Sabouraud maltose agar (SMA) with $80 \%$ seawater to induce sporulation, or stored on $2 \%$ MEA slants at $4{ }^{\circ} \mathrm{C}$. Finally, the remaining tissue and organs of each fish were examined for parasites by dissection and tissue squash procedures. All procedures were carried out according to the Department of Fisheries and Oceans, Fish Health Protection Regulations: Manual of Compliance (1984).

Histology. Samples of lesions from plaice, specimen nos. 945,977, 978 and 986, were fixed for light and electron microscopy in $1 \%$ glutaraldehyde and $4 \%$ formaldehyde, in a phosphate buffer at pH 7.2 (McDowell 1978). For light microscopy, samples were embedded in paraffin. Sections ( $6 \mu \mathrm{m})$ were stained with haematoxylin and eosin ( $\mathrm{H} \& \mathrm{E})$, the Leaver stain for bacteria, or the Gridley method for fungi. All staining methods were taken from Humason (1979). For scanning 
electron microscopy (SEM), specimens were post-fixed in $1.5 \%$ osmium tetroxide, dehydrated in ethanol followed by critical point drying, and sputter-coated with gold-palladium. They were viewed and photographed in a Hitachi S-2400 scanning electron microscope.

\section{RESULTS}

\section{Gross pathology}

Plaice necropsied 5 to 18 mo after they were first measured and weighed had grown little or not at all; mean lengths and weights were 22.75 (range 16 to 28) $\mathrm{cm}$ and 91.50 (26 to 180) $\mathrm{g}$ on 12 August 1992 and 23.88 (17 to 28) $\mathrm{cm}$ and 100.25 (35 to 181) $\mathrm{g}$ at necropsy. Circular black lesions 5 to $20 \mathrm{~mm}$ in diameter were found on the undersides of the bodies and caudal peduncles of 8 plaice, 4 of which (specimen nos. 945, 977, 978 and 986) had been used to monitor larval sealworm migration. Two lesions occurred on specimens 986 and 977 and 1 on each of the remaining 6 specimens. While large lesions had a central ulcer, the epidermis remained intact over smaller lesions (Fig. 1). The pigmentation in large lesions extended deep into the muscle tissue. Unpigmented lesions were found on the jaw of specimen no. 945 and in the eye of specimen no. 978 .

\section{Microbiology}

Livers, kidneys and gonads were negative for pathogens. A black-pigmented fungus was isolated on $\mathrm{BA}$ at $22^{\circ} \mathrm{C}$, from the dark lesions on the ventral side of the body of specimen no. 986. Fungal isolates from the lesion on no. 986 and from lesions on 2 other specimens (no. 945 and no. 978) were identified as Hormoconis resinae (Lindau) v. Arx \& de Vries based on spore and conidiophore morphology (Domsch et al. 1980). The colony on $2 \%$ MEA was slow growing, compact, with brownish-green aerial hyphae, black on reverse of agar plate. This isolate of $H$. resinae differed somewhat from the type description of the species ( $M$. Corlett pers. comm.). Although the spore morphology was normal for the species, conidiophores were rare and sporulation on $2 \%$ MEA, SDA and SMA made with either distilled water or $80 \%$ seawater occurred only after 2 to $3 \mathrm{mo}$ incubation at $25^{\circ} \mathrm{C}$. Cultures are available from the senior author.

A Vibrio sp. was cultured on TSA with $2 \%$ salt from an ulcerated lesion on specimen no. 986, and an aseptate unpigmented fungus was isolated from the eye of specimen no. 978, but these organisms were not identified further. Vibrio sp. was also isolated from lesions on the body and tail fins of tank mortalities (specimen nos. 971, 143, 958, and a fourth specimen which had lost its tag) after 4 to 6 mo in captivity.

Besides the fungal and bacterial infection, plaice were hosts to a variety of parasites including the microsporan Pleistophora hippoglossoideus; the digeneans Aporocotyle simplex (adults), Fellodistomum furcigerum (adults), Diphtherostomum microacetabulum (adults) and Stephanostomum baccatum (metacercaria); the acanthocephalan Corynosoma wegener (juveniles); the cestode Grillotia erinaceus (plerocercoids); larval nematodes Anisakis simplex, Pseudoterranova decipiens and Hysterothylacium adunca; and the ectoparasitic copepod Acanthochondria cornuta.

Fig. 1 Hippoglossoides platessoides. Ventral, pigmented lesions (L) on a juvenile American plaice (specimen no. 945) $26 \mathrm{~cm}$ in length, photographed live, before necropsy

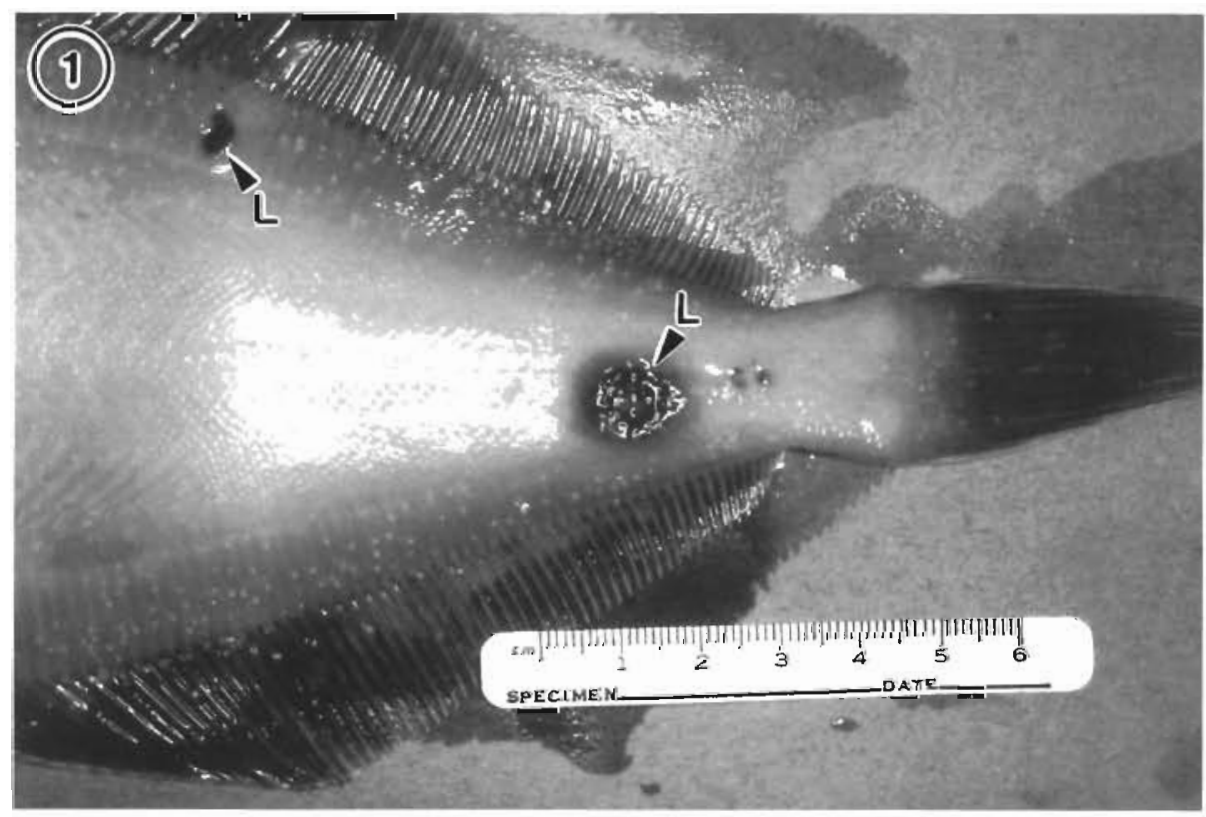




\section{Histology}

Ulcers consisted of a necrotic area surrounded by a rim of hyperplastic epidermis (Fig. 2). Necrosis extended to the muscle layer in most ulcers, and to the backbone in specimen no. 986. Clusters of rod-shaped and curved Gram-negative bacteria occupied the superficial layers of the lesion (Fig. 2). Septate, branched, pigmented fungal hyphae extended between the bacterial colonies (Figs. 2 \& 3), into the deeper necrotic tissue, and into the surrounding basal layer of the epidermis, dermis and underlying musculature. The hyphae averaged $1.8 \mu \mathrm{m}$ (range 1.6 to $2.1 \mu \mathrm{m}$ ) in diameter $(\mathrm{n}=27)$. Loss of striation and decay of muscle cells which had been penetrated by hyphae was recorded (Fig. 4). Bacteria and fungal hyphae were surrounded by numerous macrophages, and haemorrhaging was evident in some regions, especially near the base of the necrotic tissue.

In a non-ulcerous, pigmented lesion (specimen no. 986), hyphae were found on the skin surface and had penetrated the epidermis in some areas (Fig. 5), following scales into the dermal layer where there was a host inflammatory response (Fig. 6). No bacteria were evident. A fungus with unpigmented, branching, aseptate hyphae was found in a lesion in an eye of specimen 978 . No attempt was made to identify it but the non-septate hyphae and lack of pigmentation suggest it was not Hormoconis resinae.

\section{DISCUSSION}

Hormoconis resinae is common in the marine environment (Kohlmeyer \& Kohlmeyer 1979). It is an opportunistic saprophyte able to degrade a variety of recalcitrant substrates, e.g. petroleum products and creosote (Domsch et al. 1980). In the present study, $H$. resinae may have entered via wounds as is normal for opportunistic pathogens, but the hyphae also penetrated the integument directly. The extent of the tissue damage and the fact that the fungus penetrates deeply before the lesion ulcerates may suggest that the fungus can be pathogenic. The lesions were restricted to the skin and musculature, and seemed to develop slowly, appearing after the fish had been in captivity for nearly half a year. Therefore, while internal organs were not affected in the cases reported here, infection may have become systemic in time.

A well-documented case of a deuteromycetous fungal infection in the musculature of a marine fish was described by Schaumann \& Priebe (1994). In this case, Ochroconis humicola grew throughout the musculature of Atlantic salmon causing extensive necrosis, but did not form localized, deep lesions like those reported in the present study. On the other hand, ulcers, similar to those associated with Hormoconis resinae in American plaice, resulted from Ochroconis humicola infection in cultured marine devil stinger (Wada et al. 1995). Wada et al. (1995) also described superficial colonies of Gram-negative bacteria in lesions on devil stinger not unlike the opportunistic Vibrio sp. infection which we observed in sections of ulcers from plaice.

We can only speculate on the origin of the Hormoconis resinae infection in our captive plaice. Since pigmented lesions are not evident until there has been extensive hyphal growth, the fish may have been infected when captured although they showed no signs of the disease at the time. It is more likely, however, that the plaice were infected by fungi from seawater supplied to the holding tanks. Much larger organisms, such as free-living nematodes and the larvae or juveniles of various molluscs, echinoderms and crustaceans (especially harpacticoid copepods and amphipods), pass through the sand and gravel filters and establish themselves in the supply lines and tanks. The enteric digeneans Fellodistomum furcigerum and Diphtherostomum microacetabulum, with complex indirect life cycles involving molluscan and echinoderm intermediate hosts, were not detected in the plaice until they had been in captivity for more than a year. Natural infections were probably purged while the fish fasted during their first 2 wk in captivity, and, therefore, the trematodes may complete at least part of their life cycles in the tanks and/or seawater supply lines.

Figs. 2 to 6 . Hippoglossoides platessoides. Fig. 2. Section through ulcer on caudal peduncle of specimen no. 986, showing fungal hyphae (H) and clusters of Gram-negative bacteria (B) among macrophages (M) and cell debris, and a surrounding layer of hyperplastic epidermis $(E)$ which is penetrated by hyphae $(\mathrm{H})$ and vacuolated in some areas. Leaver stain for bacteria. Scale bar = $100 \mu \mathrm{m}$. Fig. 3. Surface of ulcer on specimen no. 977, showing branching fungal hyphae among macrophages and cel.l debris. SEM. Scale bar $=20 \mu \mathrm{m}$. Fig. 4. Skeletal muscle layer beneath ulcer on specimen no. 986 showing: (A) normal muscle cells with an orderly arrangement of myofibrils; (B) muscle cell, with vacuoles between the myofibrils, which has been penetrated by septate branching fungal hyphae $(\mathrm{H})$; and $(\mathrm{C})$ heavily infected cell in which the myofibrils are condensed and separated from each other by vacuolated regions. Gridley's stain. Scale bar $=20 \mu \mathrm{m}$. Fig. 5 . Fungal hyphae $(\mathrm{H})$ at the surface and within the epıdermis of a pigmented, non-ulcerous lesion on main part of body of specimen no. 986 . There are numerous vacuoles in the epidermis, some containing leukocytes (L). Gridley's stain. Scale bar $=30 \mu \mathrm{m}$. Fig. 6. Same lesion as Fig. 5. Fungal hyphae $(\mathrm{H})$ penetrate and follow the lamellae of a scale (S), and are also present in the adjacent dermal connective tissue, which contains numerous leukocytes (L). 


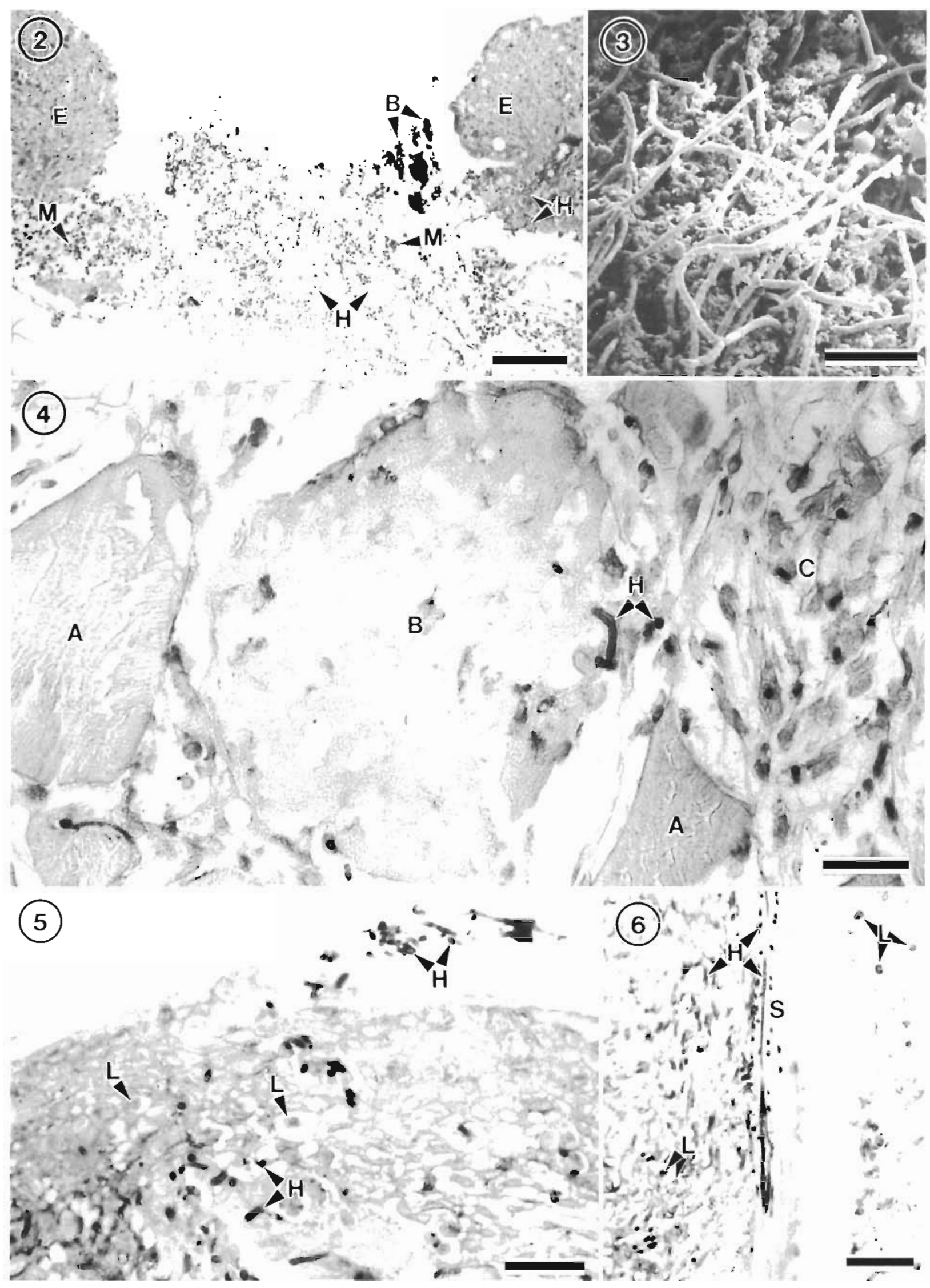


Lesions appeared on fish in both the 800 and $3200 \mathrm{l}$ tanks. They were more prevalent (4 of 22 fish) on smaller plaice which were held in the $800 \mathrm{l}$ tank and used to monitor tissue migrations of the larval nematodes Pseudoterranova decipiens. Stress or damage to the integument attributable to additional handling may have resulted in increased susceptibility to infection. Fish in the smaller tank may also have been prone to thermal stress as the temperature of the seawater supply soared as high as $15.2^{\circ} \mathrm{C}$ in late summer and fall, while not exceeding $9^{\circ} \mathrm{C}$ in the $3200 \mathrm{l}$ tank. Scotian shelf plaice naturally occur at temperatures of 1 to $13^{\circ} \mathrm{C}$, but their preferred range is 1 to $4^{\circ} \mathrm{C}$ (Scott 1982). High temperatures in the $800 \mathrm{l}$ tank may also have promoted the development and transmission of the fungus. Nutritional deficiencies resulting from restricted diet may also have rendered the fish prone to fungal infection.

As lesions continued to develop on captive plaice for more than a year after they were first observed, it is possible that the fungus was transmitted from fish to fish. We did not, however, attempt experimental transmission of this fungal isolate. The infection was probably attributable to the fact that water circulation and drainage, in both the small and large tanks, were inappropriate for flatfish holding. Water entered the tanks at the surface from overhead faucets and drained from the surface via overflow standpipes or valves. Consequently, most of the uneaten food, excretory waste and organisms transported from Halifax harbour in the water supply accumulated on the bottom where plaice may lie motionless for hours at a time. Notably, the lesions invariably occurred on the undersides of the fish, and have not been detected since the spring of 1994 when the holding tank was modified with an external standpipe drawing water from the bottom rather than the surface.

Polglase et al. (1986) describe the difficulties in gathering data to confirm the role of fungal disease in the marine environment. The prevalence of Hormoconis resinae in marine waters and its metabolic diversity suggest it could be an opportunistic pathogen on marine animals but the impact on wild populations is unknown. In September 1991, we identified Cladosporium sp. from greenish-black nodules in the meat of scallops Placopecten magellanicus harvested by commercial fishermen from the Sable Island-Western Bank complex, the same area where the plaice were captured. Although we have conducted parasitological surveys of tens of thousands of free-living American plaice, as well as other marine finfish species (McClelland et al. 1990), we cannot recall finding heavily pigmented skin lesions like those which developed in captive plaice in this study. There are no records of lesions of this type in the literature. Nevertheless, under the stressful conditions of crowding, handling and synthetic diet, typically encountered in aquaculture, opportunistic fungal pathogens like $H$. resinae must be recognized for their potential to cause mortality and to affect marketability of fish.

Acknowledgements. We thank Dr Michael P. Corlett, Centre for Land and Biological Resources Research, Ottawa, Ontario for confirming the identity of the fungus; the Fish Health Unit of the DFO Halifax Laboratory for conducting the bacteriology, Mrs C. MacDonald for expert histological assistance, and D. John Martell, Ione Hunt von Herbing and Treena Skory who assisted in capture, maintenance and necropsy of fish.

\section{LITERATURE CITED}

Alderman DJ (1982) Fungal diseases of aquatic animals. In: Roberts RJ (ed) Microbial diseases of fish. Academic Press, New York, p 189-242

Alderman DJ, Polglase JL (1986) Are fungal diseases significant in the marine environment? In: Moss ST (ed) The biology of marine fungi. Cambridge University Press, Cambridge, p 189-198

Austin B, Austin DA (1987) Bacterial fish pathogens: disease in farmed and wild fish. John Wiley and Sons, New York

Chacko AJ (1992) Fungi and oomycetes associated with fish and shellfish. In: Arora DK, Ajello L, Mukerji KG (eds) Handbook of applied mycology, Vol. 2. Marcel Dekker, New York, p 735-756

Department of Fisheries and Oceans (1984) Fish health protection regulations: manual of compliance. Miscellaneous Special Publication 31 (Revised). Fisheries and Oceans, Scientific Information and Publications Branch, Ottawa

Domsch KH, Cams W. Anderson TH (1980) Compendium of soil fungi. Academic Press, New York

Hibbets J, Hughes CC, Sparks AK (1981) Trichomaris invadens gen. sp. nov, an Ascomycete parasite of the tanner crab Chionocetes bairdi Rathbun (Crustacea, Branchyura). Can J Bot 59:2121-2128

Humason G L (1979) Animal tissue techniques, 4th edn. WH Freeman and Company, San Francisco

Kinne O (ed) (1984) Diseases of fishes, Vol [V, Part 1, Pisces. Biologische Anstalt Helgoland, Hamburg

Kohlmeyer J, Kohlmeyer H (1979) Marine mycology. The higher fungi. Academic Press, New York

McClelland G, Misra RK, Martell DJ (1990) Larval anisakine nematodes in various fish species from Sable Island Bank and vicinity. In: Bowen WD (ed) Population biology of sealworm (Pseudotersanova decipiens) in relation to its intermediate and seal hosts. Can Bull Fish Aquat Sci 222 : $83-118$

McDowell EM (1978) Fixation and processing. In: Trump BF. Jones FT (eds) Diagnostic electron microscopy. John Wiley and Sons, New York, p 113-139

Miller JD, Flemming LC (1983) Fungi associated with an infestation of Pseudocarcinonemertes homeri on Homarus americanus. Trans Br Mycol Soc 80:9-12

Noga EJ (1990) A synopsis of mycotic diseases of marine fishes and invertebrates. In: Perkins FO, Cheng TC (eds) Pathology in marine science. Academic Press, New York, p 143-160

Noga EJ (1993) Fungal diseases in marine and estuarine fishes. In: Couch JA, Fournie JW (eds) Pathobiology of marine and estuarine organisms. CRC Press, Boca Raton, p 85-109 
Polglase JL, Alderman DJ, Richards RH (1986) Aspects of the progress of mycotic infections in marine animals. In: Moss ST (ed) The biology of marine fungi. Cambridge University Press, Cambridge, p 155-164

Polglase JL, Dix NJ, Bullock AM (1984) lnfection of skin wounds in the lesser octopus liledone carrhosa by Cladosporium sphaerospermum. Trans Br Mycol Soc 82: 577580

Reichenbach-Klinke HH (1956) Über einige bisher unbekannte Hyphomyceten bei verschiedenen Süßwasser- und Meeresfischen. Mycopathol Mycol Appl 7:333-347

Roberts RJ (1989) Fish pathology, 2nd edn. Bailliere Tindall, London

Responsible Subject Editor: D. W. Bruno, Aberdeen, Scotland, UK
Schaumann K, Priebe K (1994) Ochroconis humicola causing muscular black spot disease of Atlantıc salmon (Salmo salar). Can J Bot 72:1629-1634

Scott JS (1982) Depth, temperature and salinity preferences of common fishes of the Scotian Shelf. J Northwest Atl Fish Sci 3:29-39

Shieh HS (1980) Studies on the nutrition of a fish pathogen, Flexibacter columnaris. Microbios Lett 13:129-133

Sindermann C J (1990) Principal diseases of marine fish and shellfish, 2nd edn. Academic Press, New York

Wada S, Nakamura K, Hatai K (1995) First case of Ochroconis humicola infection in marine cultured fish in Japan. Fish Pathol 30:125-126

Manuscript first received: June 27, 1996

Revised version accepted: October 4, 1996 